\title{
Project Orientation of Polish Universities
}

\author{
Małgorzata Baran \\ Collegium Civitas, Warsaw, Poland \\ Jacek Strojny \\ Rzeszow University of Technology, Rzeszow, Poland
}

\begin{abstract}
This article presents the issue of project orientation in Polish universities. The presented problem is, however, general, at least in the context of the higher education sector in countries which dominate the model of Humboldt's university. The research was placed in Polish reality and the results presented in the paper were obtained on the basis of the assessment of the level of project orientation in a group of 10 Polish universities. The research is mainly focused on the verification of the utility of the ProFive model as a tool to measure and assess the level of project orientation in universities. Henceforth, the selection of the sample is intentional and serves to verify the correctness of the inference of the model for the studied sector. It is not the intention to evaluate the situation in the whole population of Polish universities. The article consists of an introduction, a brief review of the literature, description of methodology, presentation of research results, and conclusions. The obtained results will improve the model of project orientation for the assessment of the situation in universities. Thanks to this, the verified tool can be a useful research instrument in the pre-analysis phase in all such institutions, which begin the implementation of the project approach.
\end{abstract}

Keywords: project management, project orientation, systemic management, maturity models, universities

\section{Introduction}

The modern economy is often stated as a knowledge-based economy (KBE) (Harris, 2001), in which a great role is played by the process of creating, distributing, and processing knowledge, both within the organization and between organizations and sectors as well. It also stresses the growing significance of innovation as a tool to compete in today's markets (Platonoff, Sysko-Romańczuk, \& Moszoro, 2004; Cooke, 2001). In this context, it is worth considering the importance of institutions, which are called to life to create and disseminate knowledge. In Poland, as in most countries of continental Europe, the so-called Humboldt model of the university became widespread (Antonowicz, 2005; Boguski, 2009; Fallon, 1980). It assumes a separation in the process of knowledge creation and transfer from external phenomena in the economy. This is due to the intention to preserve the purity of science (Lüde, 2012). It determines the way of functioning of modern universities, influencing both the career development processes and the structure of university organization as well. It is also still present in the minds of the scientific community. Such an approach, however, makes it difficult to develop actions that are expected from modern universities. These institutions,

Małgorzata Baran, Ph.D., Collegium Civitas, Warsaw, Poland.

Jacek Strojny, Ph.D., Rzeszow University of Technology, Rzeszow, Poland.

Correspondence concerning this article should be addressed to Jacek Strojny, Department of Economics, Rzeszow University of Technology, Av. Powstańców Warszawy 12, 35-959 Rzeszów, Poland. 
according to the innovation policies in the European Union, should play the role of an active partner acting for innovation of regions or countries (Prawelska-Skrzypek, 2012). Hence the concepts of the entrepreneurial university (Boguski, 2009; Clark, 2001; Etzkowitz, 2004) are both organizationally and culturally ready to proactively join a mechanism for the creation and transfer of knowledge. Such a university is characterized by significant involvement of the academic community in creating the mechanisms for the commercial utilization of knowledge (Bercovitz \& Feldman, 2006). This means that all phases of knowledge creation range from the creation of an idea and end with its implementation into the real economy subordinate for the defined target group of customers. Such a scheme of knowledge creation stands in clear contradiction to the idea of purity of knowledge, which is characteristic of the Humboldt model of the university.

Taking into consideration the above-mentioned aspects, the aim of this article is proposed. This is to present the assumptions of a project-oriented university, which is the extension of the concept of the entrepreneurial university model. In developing the concept, the study was conducted in 10 Polish universities using the ProFive model of project orientation (Baran \& Strojny, 2013; Baran, Kłos, \& Strojny, 2015). A study allowed evaluation of the level of project orientation in the group of universities investigated. On the basis of this, general cognitive and methodological conclusions were made.

\section{Project Orientation of the Universities}

In the Polish legal system, universities are autonomous institutions, guided by the principles of freedom of teaching, scientific research, and artistic creation (Parliament, 2005). They should also cooperate with the socioeconomic environment, particularly in the field of research and development (E\&Y, IBGR, 2010). European mechanisms such as the ERA-European Research Area (European Commission, 2012) or the IU-Innovative Union (European Commission, 2015) are important platforms in the process of improving the active role of universities in creating knowledge transfer mechanisms, and therefore also of economic growth. In the context of these global, European, and national formal frameworks, the possibility of transforming the model of the functioning of Polish universities should be considered.

The foundation of the modern university is the concept of Humboldt established in the 19th century on the basis of the University of Berlin (Fallon, 1980). The main purpose of higher education in this model is an autonomous (not contaminated by external influences) search for the truth. This model, despite the recognition of research rationalism and the need for positive impact on society, rejects research under the pressure of the environment and a product-based approach in identifying market needs (Strojny, 2013). Therefore, now it is increasingly highlighting the need for evolution towards the so-called third generation university model (Wissema, 2009). It constitutes the development of the Anglo-Saxon model specific to island countries in Europe, North American countries, Australia, as well as New Zealand. This Anglo-Saxon model differs significantly from Humboldt at many levels. From the perspective of this article, an important issue is the mission of such institutions and commitment to real economic processes (Leja, 2013).

Universities are regarded as an important component of economic development mechanisms and the reputation of the institution depends largely on the level of innovation and quality of applications of the research results in the economy. Both in teaching and research, these organizations are subject to considerable competitive pressure, which forces taking actions closely related to the expectation of the market. From the point of view of the challenges facing the European Union and countries, such as Poland, it seems necessary to search for ways for universities to evolve. The implementation of solutions aimed at increasing the flexibility of 
universities in creating and transferring knowledge should be taken into account. In this arrangement, the concept of the third generation university constitutes some kind of target model. This is because it assumes the implementation of mechanisms that significantly enhance the role of the sector of science and higher education in creating added value in the economy. First of all, in this model, the role of scientist-entrepreneur is emphasized, who skillfully identifies the needs of customers and provides socially useful and commercially validated innovative solutions based on their research. The key to the development of this type of model is the start-up of a so-called academic entrepreneurship, which is based on the production and distribution of know-how (Biały, 2011).

Such an entrepreneurial university requires a significant change in the management process and implementation of approaches that ensure the effective and flexible implementation of projects for the economy. Simultaneous implementation of many projects at numerous different levels and in cooperation with a large number of factors outside the university forces significant decentralization of management. The functioning of the university should be based on mobile research teams of scientists, often working in interdisciplinary structures. This means that it is reasonable to complement the third generation university model through project orientation, focusing on the mechanisms of management in this type of system. A scheme of this approach is shown in Figure 1.

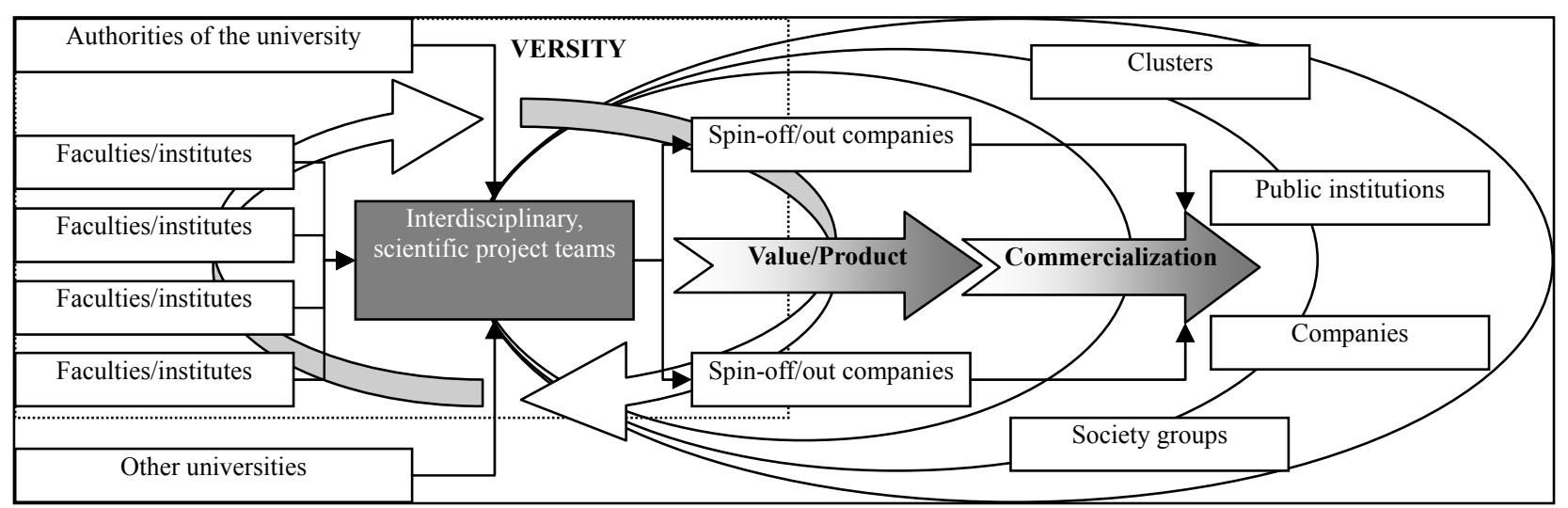

Figure 1. The model of value creation in a project-oriented university.

In this model, the main mechanism for creating value for the environment (effects of research provided to commercialization) is based on the functioning of interdisciplinary research teams. They operate on the basis of resources (people, finances, and infrastructure) allotted to the project by the departments, institutes or faculties - linear cells of the university. In addition, the whole process of planning, execution, and settlement of projects is carried out in the framework of a general project management system in the university. These tasks should be assigned to the organizational unit which is called the PMO - project management office. Interdisciplinary teams are formed from the bottom up, based on contacts and market analysis provided by researchers-leaders who coordinate the manufacturing process of the identified customer groups. Important in the whole process is a systematic approach to managing teams and projects, based on uniform procedures and the use of dedicated tools to support this process.

It is proposed that the operation of universities functioning according to the above-described model based on the project management method, whose origins are commonly associated with the Manhattan Project (works on developing a nuclear bomb) implemented during World War II (Seymour \& Hussein, 2013). In the second 
half of the 20th century, this method was also fairly quickly applied in the business sphere. Two major and well-known contemporary approaches to project management were created: the PMI—Project Management Institute in the USA; and the IPMA - International Project Management Association in continental Europe (Austria and Germany) (Kwak, 2003). Successively, the "PRINCE2" methodology was established, which is also currently a very popular approach in the world (Kwak, 2003). Institutions and companies that have adopted system solutions using the project management method are project-based organizations. The project orientation is a way of governance, in which a large part of tasks are performed as a project and the entire organization is focused on achieving high efficiency and effectiveness in this type of project (Lampel \& Pushkar, 2004; Munns \& Bjeirmi, 1996). Project-based organizations stand out from others in terms of culture and organizational structure, applicable procedures, and management techniques.

The growing popularity of the method increases the demand for a variety of standards that allow adjusting the project orientation and assessment of its level. These are called project maturity or project excellence models. As a part of the main methodologies, the following models were created: the IPMA delta model (IPMA, 2013), the PMI organizational project maturity model (PMI, 2013), and within PRINCE2 - the portfolio, the programme and project management maturity model (Office of Government Commerce, 2009). Other concepts of assessing project orientation are also common (Kerzner, 2011; 2013; Gareis, 2005; Kwak \& Ibbs, 2000; Rodney \& Müller, 2003; L. Y. Zhang, He, \& X. X. Zhang, 2012; Andersen \& Jessen, 2003). Both the dimensions and the level of project maturity/excellence in different organizations or branches are tested using the models (Andersen \& Jessen, 2003; Grant \& Pennypacker, 2006; Baran \& Strojny, 2013). The financial and organizational effects of the project orientation are also analyzed (Cooke-Davies \& Arzymanow, 2003). In this article, the starting point for assessing the project orientation is the concept of ProFive created by Strojny and Witkowski, covering five dimensions of project management excellence in the organization. These are shown in Table 1.

Table 1

Dimensions of the ProFive Model

\begin{tabular}{|l|l|l|}
\hline \multicolumn{2}{|l|}{ Project-oriented organization-Main dimensions } \\
\hline 1. & Project culture & $\begin{array}{l}\text { Characteristics of organizations that provide a high importance of projects, the existence } \\
\text { of the project management system, and organizational and utility assistance for projects }\end{array}$ \\
\hline 2. & Project team management & $\begin{array}{l}\text { The rules adopted for competency development of project team members, the role and } \\
\text { powers of the project manager, and the principle of appointing motivation and } \\
\text { communication among project team members }\end{array}$ \\
\hline 3. & Strategic management & $\begin{array}{l}\text { Mechanisms for describing the relationship between projects and strategy, principles for } \\
\text { the evaluation, and selection of projects and for the management of their portfolio from } \\
\text { the point of view of the objectives of the organization as a whole }\end{array}$ \\
\hline 4. & Project management & $\begin{array}{l}\text { Management principles of the project lifecycle model and therefore the phases of } \\
\text { initiation, definition, planning, implementation, and closing of projects }\end{array}$ \\
\hline 5. & $\begin{array}{l}\text { Comprehensive approach to } \\
\text { project management }\end{array}$ & $\begin{array}{l}\text { Mechanisms to ensure more efficient processes of managing projects by running } \\
\text { relationships with stakeholders, risk management, quality management, finance } \\
\text { management, and project documentation }\end{array}$ \\
\hline
\end{tabular}

\section{Research Methodology}

The authors conducted a study of the project maturity in the group of 10 Polish universities in the years 2014-2015. The applied research technique was a straightforward standardized interview (questionnaires): the PAPI - paper \& pen personal interview. The study was carried out by a qualified research team who conducted the interview with the managers of projects at the university and working in the following positions: vice-rector, 
chancellor, dean, as well as managers of PMO's and project coordinators. The study involved universities, for which there was information that they actively raise external resources for projects and have at least four years of experience in projects realization. The main objective of the study was to determine how mature/excellent the practices of project management applied in the surveyed universities are. The tested universities belong to a group of small and medium universities (below 4,000 students). In this group, seven universities represent the private education sector and three are public universities.

The survey used the ProFive questionnaire in which each of the five dimensions characterized in the previous chapter was divided into five specific indicators. Each of these indicators is evaluated based on answers to five questions concerning the situation in the university. Respondents provided answers based on the Likert scale (from 1 to 5, with 1 being definitely not, while 5-definitely yes). These answers determine the assessment of the level of project maturity/excellence of each indicator (parameter). On this basis, the valuation of each dimension is made and then the general mark of project orientation level is calculated. Marks at a higher level of the model are calculated as the arithmetic mean of the lower level.

\section{The Level of Project Orientation in Chosen Polish Universities}

The designed assessment questionnaire collected information on the specific characteristics of project orientation in the group of universities. Summary results of the survey, including mean scores of the level of project maturity/excellence for the entire group of universities are shown in Table 2.

Table 2

The Level of Project Orientation in the Surveyed Universities

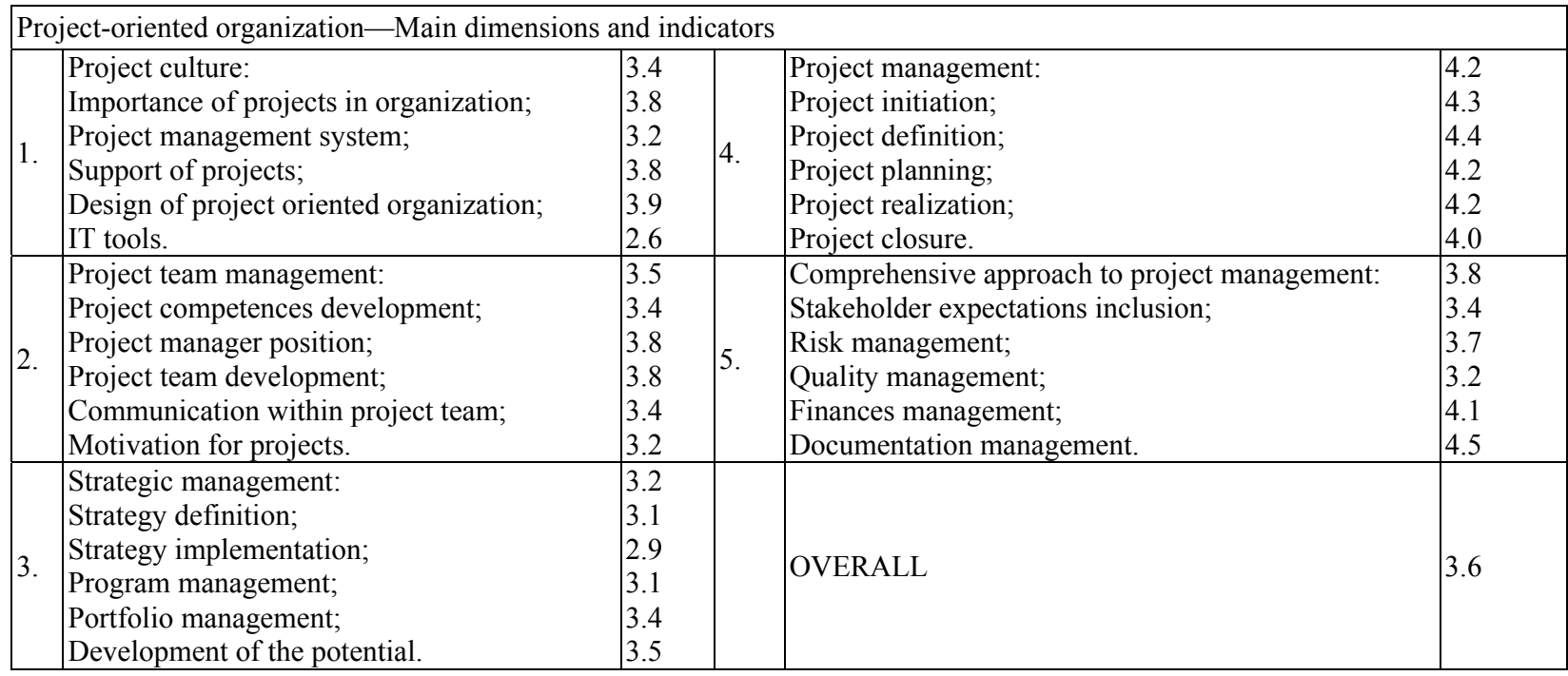

The study of project orientation of any organization is an assessment of the basic elements of the project management process and the internal environment of this process (Baran \& Strojny, 2013). One of the five key areas of effective implementation of project management processes is project culture. In the group of universities, its level rated at 3.4. A similarly evaluated dimension of project orientation is project team management (score 3.5). It is focused on the process of the team design, team competences, motivation, and communication within the team. The surveyed universities emphasize the importance of projects, the selection of team members, and the support of project teams. An expression of it is, among other PMOs, established 
within the structures of universities (eight of 10 respondents have such units in their structures). These specialized cells deal with the coordination of projects, the building of a knowledge base, as well as the training of project staff. However, only half of those surveyed universities draw attention in their activities for systemic organizational solutions. Only three universities have organizational rules that favor the realization of projects, while seven respondents did not apply the tools for the planning and monitoring of projects. In four universities, the coding system of projects and tasks in projects is used. Only half of the respondents have categorization of projects, the use of guidance, and perform regular audits of the project management system to facilitate it. Supporting the process of project management tools is the lowest scored element of project orientation (2.6 pts), in each of the surveyed universities, there is a lack of IT tools - dedicated software solutions for the planning and realization of projects; and enabling monitoring, reporting, and assessment of the situation of the project, the portfolio of the project, and program.

The least assessed dimension of project orientation is strategic management, linking the area of project management with the strategy of universities (score 3.2). Each of the surveyed universities indeed has a written strategy of development, but only in half of them, the strategy contains clearly defined, measurable targets, specifying the time horizon of their planned implementation. This is strongly recommended in setting the framework for the projects. At the same time, periodical reviews and updates of the provisions of the strategy are not made, which undoubtedly have an impact on the scope of the projects and an assessment of their compliance with the strategy of the university. Projects are selected and planned with regard to optimizing the use of university resources. Development of the resources of universities is planned and implemented. A systematic analysis of the use of these resources (equipment, buildings, etc.) is also carried out. At the same time, efforts are aimed at increasing the efficiency of the organization's resources. Universities also support the development potential of their providers.

The fourth dimension of project orientation of the university is project management. It refers to the five phases of the project life cycle model: initiation, definition, planning, realization, and closing. It is the highest rated dimension (score 4.2). This demonstrates a good knowledge of project management methodologies and the extensive experience of all universities in projects realization in accordance with PCM methodology.

The last of these dimensions of project orientation is a comprehensive approach to project management with a mark of 3.4 points. It provides a high level of project awareness of universities in both project implementation and project management. The survey results show that taking into account the expectations of stakeholders is important for determining the implications of the project. Unfortunately, that is only in the case in private universities, which adapt to market requirements in a more flexible way than public universities. Respondents acknowledge that projects realization raises the need to develop a system of management control; but universities do not have a systematic approach to risk management. In the investigated group, there is also the lack of effective quality management. Only two non-public schools have implemented comprehensive quality management programs. None of the public universities have implemented a quality system. However, other element, such as a financial management and planning and controlling projects from a cost perspective, is an important part of project management for all of the examined universities. The ongoing analysis of budgets allowing for a reliable valuation of the tasks carried out within the projects is conducted, while only every third universities have implemented a controlling process, which allows the provision of full control of costs. 


\section{Conclusions}

Building or transforming the university into a project-oriented organization requires implementation of both procedural and organizational changes (Baran et al., 2015). As the results of the research provided, despite actively pursuing projects, the assessed universities are not project-oriented organizations. They have not adapted the appropriate organizational structure, do not use IT tools or adequate procedures, as well as selectively implement techniques of project management. These are all the main barriers to the realization of projects in the surveyed organizations. While project management is a very important area of activity for each university, there is a significant potential for improvement in terms of project orientation. The general mark of the level of project orientation is only 3.6. In particular, improvements require the following dimensions: strategic management (3.2 pts) and project culture ( $3.4 \mathrm{pts})$. At the same time, it is worth noting that the surveyed universities developed the project management process at a relatively high level (4.2 pts).

The tested ProFive model allowed the diagnosis of general areas for improvement of universities. Definition of the main problems and the core strengths of each entity were also possible. Modifications of the methodology of research should be subjected to data collection. It is worth modifying the PAPI method and implementing focus interviews, obtaining more complete feedback, rich in detail to provide a better understanding of the organization. This is especially important, if the ProFive model will be regarded as a tool of pre-analysis methodology and not just as an instrument for research. The second potential direction of the methodological development of research is to change the method of calculating aggregate ratings. The use of arithmetic means is not the ideal mechanism for the calculation of the aggregated indicators. It should include the weights of the individual components of the model. Here, an interesting solution to support the research process seems to be one of the most advanced multi-criteria analysis methods, the AHP (Saaty, 1980).

\section{References}

Andersen, E. S., \& Jessen, S. A. (2003). Project maturity in organizations. International Journal of Project Management, 21, 457-461.

Antonowicz, D. (2005). Uniwersytet przyszłości: Wyzwania i modele polityki. Warsaw: Instytut Spraw Publicznych.

Baran, M., \& Strojny, J. (2013). Kompleksowe podejście do zarządzania projektami na przykładzie uczelni wyższej. In E. Gołębiowska (Ed.), Zarzqdzanie w XXI wieku (pp. 250-262). Łódź: Wydawnictwo SAN.

Baran, M., Kłos, M., \& Strojny, J. (2015). Kultura projektowa w procesie zarządzania projektami na uczelniach wyższych-Wyniki badania. In E. Stroińska and Ł. Sułkowski (Eds.), Determinanty zarzqdzania projektami i procesami w organizacji (pp. 191-216). Łódź-Warszawa: Wydawnictwo SAN.

Bercovitz, J., \& Feldman, M. (2006). Entrepreneurial universities and technology transfer: A conceptual framework for understanding knowledge-based economic development. The Journal of Technology Transfer, 31(1), 175-188.

Biały, K. (2011). Przemiany współczesnego uniwersytetu: Od idei von Humboldta do modelu uczelni przedsiębiorczej. Łódź: Wydawnictwo Uniwersytetu Łódzkiego.

Boguski, J. (2009). Od uniwersytetu tradycyjnego do uniwersytetu przyszłości. Nauka i Szkolnictwo Wyższe, 1(33), 25-33.

Clark, B. (2001). The entrepreneurial university: New foundations for collegiality, autonomy, and achievement. Higher Education Management, 13(2), 9-24.

Cooke, P. (2001). Regional innovation systems, clusters, and the knowledge economy. Industrial and Corporate Change, 10(4), 945-974.

Cooke-Davies, T. J., \& Arzymanow, A. (2003). The maturity of project management in different industries: An investigation into variations between project management models. International Journal of Project Management, 21, 471-478.

E\&Y, IBGR. (2010). Strategia rozwoju szkolnictwa wyższego w Polsce do 2020 roku (Raport cząstkowy). Warszaw: Ernst \& Young Business Advisory, Instytut Badań nad Gospodarką Rynkową. 
Etzkowitz, H. (2004). The evolution of the entrepreneurial university. International Journal of Technology and Globalisation, 1(1), 64-77.

European Commission. (2012). Communication from the commission to the European Parliament, the Council, the European Economic and Social Committee of the Regions. Brussels: European Commission.

European Commission. (2015). State of the Innovation Union. Luxembourg: Publications Office of the European Union, European Commission.

Fallon, D. (1980). The German university. A heroic ideal in conflict with the modern world. Boulder: Colorado Associated University Press.

Gareis, R. (2005). Happy projects. Vienna: Manz.

Grant, K. P., \& Pennypacker, J. S. (2006). Project management maturity: An assessment of project management capabilities among and between selected industries. Engineering Management, IEEE Transactions, 53, 59-68.

Harris, R. G. (2001). The knowledge-based economy: Intellectual origins and new economic perspectives. International Journal of Management Reviews, 3(1), 21-40.

International Project Management Association. (2013). IPMA organizational competence baseline-The standard for moving organizations forward. Zurich: International Project Management Association.

Kerzner, H. R. (2011). Using the project management maturity model: Strategic planning for project management. Ohio: John Wiley \& Sons.

Kerzner, H. R. (2013). Project management: A systems approach to planning, scheduling and controlling (11th ed.). Ohio: John Wiley \& Sons.

Kwak, Y. H., \& Ibbs, C. W. (2000). Assessing project management maturity. Project Management Journal, 31, 32-43.

Kwak, Y. H. (2003). A brief history of project management. In G. Carayannis, Y. H. Kwak, and F. T. Anbari (Eds.), The story of managing projects. Westport: Quorum Books.

Lampel, J., \& Pushkar, P. J. (2004). Models of project orientation in multiproject organizations. In P. W. J. Morris and J. K. Pinto (Eds.), The Wiley guide to managing projects (pp. 223-236). Hoboken, NJ: John Wiley \& Sons.

Leja, K. (2013). Zarzqdzanie uczelniq: Koncepcje $i$ wspótczesne wyzwania. Warszaw: Wolters Kluwer.

Lüde, R. V. (2012). From Humboldt to market. State and Market in Higher Education Reforms, 13, 149-164.

Munns, A. K., \& Bjeirmi, B. F. (1996). The role of project management in achieving project success. International Journal of Project Management, 14, 81-87.

Office of Government Commerce [OGC]. (2009). Managing successful projects with PRINCE2TM. London: TSO.

Parliament. (2005). Higher education act. Warsaw: Parliament.

Platonoff, A. L., Sysko-Romańczuk, S., \& Moszoro, M. (2004). Innowacyjność polskich firm w gospodarce opartej na wiedzy. Ekonomika i Organizacja Przedsiębiorstwa, 1, 86-94.

Prawelska-Skrzypek, G. (2012). Zmieniająca się rola uniwersytetów w regionalnej polityce innowacyjnej. Samorzqd Terytorialny, 10, 21-27.

Project Management Institute. (2013). Organizational project management maturity model (3rd ed.). Pennsylvania: Project Management Institute.

Rodney, T. J., \& Müller, R. (2003). On the nature of the project as a temporary organization. International Journal of Project Management, 21, 1-8.

Saaty, T. L. (1980). The analytic hierarchy process. New York: McGraw-Hill.

Seymour, T., \& Hussein, S. (2013). The history of project management. International Journal of Management \& Information Systems, 18, 233-240.

Strojny, J. (2013). Cele i kierunki wspótpracy nauki z przemysłem. Rzeszów: Oficyna Wydawnicza Politechniki Rzeszowskiej.

Wissema, J. G. (2009). Towards the third generation university: Managing the university in transition. Cheltenham: Edward Elgar Publishing.

Zhang, L. Y., He, J., \& Zhang, X. X. (2012). The project management maturity model and application based on PRINCE2. Procedia Engineering, 29, 3691-3697. 